\title{
Performance of tomato cultivars transplanted on various dates under the agro-climatic conditions of district Buner
}

\author{
Faraz Ali Shah ${ }^{1 *}$, Ghulam Nabi ${ }^{1}$, Muhammad Noman Khan ${ }^{1}$, \\ Shafiullah ${ }^{2}$, Shah Rukh ${ }^{1}$, Saeed Ur Rahman ${ }^{1}$ and Sayed Minhaj Ali \\ Shah $^{3}$
}

1. Department of Horticulture, The University of Agriculture, Peshawar-Pakistan

2. Department of Horticulture, Agricultural Research Station Amnawar-Buner

3. Department of Agronomy, The University of Agriculture, Peshawar-Pakistan

*Corresponding author's email: farazali736@gmail.com

Citation

Faraz Ali Shah, Ghulam Nabi, Muhammad Noman Khan, Shafiullah, Shah Rukh, Saeed Ur Rahman and Sayed Minhaj Ali Shah. Performance of Tomato Cultivars Transplanted on Various Dates under the Agro-Climatic Conditions of District Buner. Pure and Applied Biology. Vol. 10, Issue 2, pp416-429.

http://dx.doi.org/10.19045/bspab.2021.100045

Received: 19/07/2020 Revised: 26/09/2020

Accepted: 02/10/2020

Online First: 08/10/2020

\section{Abstract}

The performance of tomato cultivars transplanted on various dates under the agro-climatic conditions of District Buner was carried out at Agricultural Research Station Buner, Khyber Pakhtunkhwa during the year 2019. The treatments were arranged in split plot using RCBD which were replicated thrice. There were two factors, Factor-A was the transplantation date $\left(13^{\text {th }}, 20^{\text {th }}, 27^{\text {th }}\right.$ March and $03^{\text {rd }}$ April) which were subjected to the main plot and Factor-B was cultivars (Anna, Sahil and Summer Red) which were assigned to the sub plot. The data was recorded on various parameters which includes plant height, stem diameter, flowering days, branches plant ${ }^{-1}$, days to harvesting, fruits plant ${ }^{-1}$, fruit weight, fruit diameter, fruit drop, total soluble solids, yield and disease incidence. Results showed that majority of the parameters were affected significantly by transplanting dates and cultivars. In transplantation dates the tallest plant $(246.83 \mathrm{~cm})$, maximum branches plant ${ }^{-1}(42.30)$, fruits plant $^{-1}(81.50)$, fruit weight $(128.46 \mathrm{~g})$, fruit diameter $(4.98 \mathrm{~cm})$, yield $\left(92.72\right.$ tons $\left.\mathrm{ha}^{-1}\right)$, least fruit drop $(5.86 \%)$ and disease incidence $(2.60 \%)$ were recorded when transplantation was practiced on $13^{\text {th }}$ March. In case of cultivars, Anna resulted in tallest plant $(258.37 \mathrm{~cm})$, more branches plant ${ }^{-1}(41.73)$, fruits plant ${ }^{-1}(80.58)$, fruit weight $(133.43 \mathrm{~g})$, fruit diameter $(5.00 \mathrm{~cm})$, yield $\left(95.16\right.$ tons ha- $\left.{ }^{-1}\right)$, lowest fruit drop $(4.87 \%)$ and disease incidence $(2.30 \%)$. It can be concluded that Anna cultivar transplanting on $13^{\text {th }}$ March could be followed for having better growth, higher yield and quality of tomato at the agro-climatic conditions of District Buner.

Keywords: Different Dates; District Buner; Tomato Cultivars

\section{Introduction}

Tomato (Lycopersicum esculentum L.) is the most common as well as extensively grown vegetable all over the world [1]. It is one of the members of Solanaceae family; this family has over 3000 species. It was originated in South America [2]. After potato, it is the second most produced 
vegetable around the world [3]. In Pakistan tomatoes are grown twice in a year (summer and winter); the winter crop is restricted to frost-free areas such as Dargai [4]. Tomato is an annual plant which can reach to a height of about 2 meters [5]. Tomato is economically an important crop, the area under its cultivation is expanding day by day because tomato is a short duration crop and provides higher yield. Tomato is the main component in many diets and contains vitamins like $\mathrm{A}, \mathrm{C}, \mathrm{E}$, and $\mathrm{K}$; it has also minerals like Calcium, potassium and phosphorus [6]. Tomatoes are important in curing of several cancer types and cardiovascular diseases due to the presence of lycopene which is a leading antioxidant [7]. Tomato is consumed in many ways like sun dehydrated tomatoes, tomato soup, tomato extract, ketchup and fresh in the form of salad [8]. Tomato's need relatively cool and dry climate, grows well in sandy loam with ideal $\mathrm{pH}$ of 6-6.5, for tomato cultivation 25 to $29{ }^{\circ} \mathrm{C}$ is considered as the ideal temperature [9].

In Pakistan tomato was cultivated on approximately 63203 hectares and overall production was 601098 tons [10]. In Khyber Pakhtunkhwa, tomatoes were grown over 9408 hectares during Kharif season and on 3135 hectares in Rabi season produced 81214 and 37556 tons, respectively [11].

Transplanting time can greatly influence tomato fruits yield because of different agroclimatic conditions, the fruit thickness of tomato is affected by the date of transplantation [12]. [13] stated that the earliest sowing date leads to a higher yield as compared to the later sowing date during studying the transplantation effect on tomatoes. Transplanting time had greatly influence the growth and production of tomato crop [14]. [15] stated that tomato yield and branches plant ${ }^{-1}$ was greatly reduced with the late transplanting dates. Better vegetable quality and yield can be obtained by suitable planting dates [16]. In terms of yield the earlier planting date of tomato achieved better results instead of late planting date [17]. The yield of tomato was found declined by planting later [18].

Cultivar selection is an important process because high yielding cultivar is one of the key element for uniform vegetable production. Farmers have no idea in selection of right cultivar thus still using the ancient cultivars; there is a need of high yielding tomato cultivars for boosting the tomato production and income of the farmers. Yield and better quality of tomato depends on the proper selected cultivar.

During the year 2018 before the conduction of this experiment, the tomato yield was greatly declined due to number of reasons through which most of the farmers were adversely affected. In District Buner tomato plants died approximately three months earlier from their peak time due to which the farmers faced huge loses. The Agricultural Extension Department Buner arranged a meeting with the local farmers through the collaboration of Agricultural Research Department Buner, according to their views some farmers declared that it was due to the poor seed quality while others blamed the sowing and transplanting dates of the tomato crop, whereas some farmers raised objections on the performance of tomato cultivars. So the reason behind this experiment was to test the various transplanting dates as well as best and suitable cultivar of tomato for District Buner to minimize the loses of farmers and to boost the income of farming community, which may help in decreasing the loss of farmers in coming years by knowing the proper tomato cultivar and proper time of tomato transplants. Thus the objectives of the study was to find out the best transplanting date for tomato and to explore the best tomato cultivar in District Buner 
having maximum growth, higher yield as well as superior quality.

\section{Materials and Methods}

The study "performance of tomato cultivars transplanted on various dates under the agroclimatic conditions of District Buner" was conducted at Agricultural Research Station Buner, Khyber Pakhtunkhwa during the year 2019 which lies at $34^{\circ} 48^{\prime} \mathrm{N}$ Latitude and $72^{\circ} 57^{\prime}$ E Longitude. The annual rainfall in the locality is $672-1198 \mathrm{~mm}$.

\section{Experimental design}

The treatments were assigned in split plot using (RCBD) consisted of 2 factors and was replicated thrice. Factor-A was transplantation dates which were subjected to main-plot whereas Factor-B was cultivars and were assigned to sub-plot (Table 1). Planting distance was $30 \mathrm{~cm}$ while Row spacing was $75 \mathrm{~cm}$. 2.5 feet distance was kept between replication and same was left on all sides of the field. The size of the main plot was $\left(9.45 \mathrm{~m}^{2}\right)$ and sub plot was kept $\left(3.15 \mathrm{~m}^{2}\right)$. All the seeds were collected from Agricultural Extension Department Buner Government of Khyber Pakhtunkhwa. The nursery was grown from mid-February till the start of March while transplantation from the nursery bed to the field was done 30 days after the seed sowing.

Table 1. Shows factors

\begin{tabular}{|c|c|}
\hline Factor A: & Factor B: \\
\hline Transplanted date (Main-plot) & Tomato cultivars (Sub-plot) \\
\hline TD1 $=13^{\text {th }}$ March & Cv.1 $=$ Anna \\
\hline TD2 $=20^{\text {th }}$ March & Cv.2 $=$ Sahil \\
\hline TD3 $=27^{\text {th }}$ March & Cv.3 $=$ Summer Red \\
\hline TD4 $=03^{\text {rd }}$ April \\
\hline
\end{tabular}

\section{Management practices}

In the start of the experiment approximately nine wheelbarrow of well rotten farm yard manure were spread in the field before cultivation. After first hoeing $5 \mathrm{~kg}$ single super phosphate were applied with the first irrigation. Insecticides were applied for the control of "cutworms" at the interval of ten days. Fungicides were sprayed after every ten days for the control of "Early blight" and "Late blight" diseases. A mixture of $5 \mathrm{~kg}$ Sulphate of Potash, $2 \mathrm{~kg}$ Urea and $2 \mathrm{~kg}$ Diammonium Phosphate were made and placed on both sides of each plant. All the plots were irrigated once in a week. The hoeing and weed eradication were practiced accordingly.

\section{Parameters studied}

The data were obtained on the following mentioned parameters.

1. Plant height $(\mathrm{cm})$
2. Stem diameter $(\mathrm{cm})$

3. Days to flowering

4. Number of branches plant ${ }^{-1}$

5. Days to harvesting

6. Number of fruit plant $^{-1}$

7. Fruit weight (g)

8. Fruit diameter $(\mathrm{cm})$

9. Fruit drop (\%age)

10. Total soluble solids ( ${ }^{\circ}$ Brix)

11. Yield (tons $\mathrm{ha}^{-1}$ )

12. Disease incidence (\%age)

\section{Statistical procedure}

The computer statistical software Statistix (8.1) was used for ANOVA as well as for LSD at 5\% probability level [19].

\section{Results and Discussion}

Plant height (cm)

Data recorded on plant height $(\mathrm{cm})$ are tabulated in (Table 2), which showed that 
the plant height $(\mathrm{cm})$ was significantly varied between the transplantation dates and cultivars, while the interaction showed nonsignificant results. The mean table showed that the tallest plant $(246.83 \mathrm{~cm})$ was noted on transplantation date $13^{\text {th }}$ of March, followed by transplantation date $20^{\text {th }}$ March $(238.81 \mathrm{~cm})$, whereas the shortest plant $(224.20 \mathrm{~cm})$ was noted in transplantation date $03^{\text {rd }}$ April which was found statistically at par with $27^{\text {th }}$ March $(227.37 \mathrm{~cm})$. Means about the cultivars showed that tallest plant $(258.37 \mathrm{~cm})$ was resulted in cultivar Anna, followed by Sahil cultivar $(241.05 \mathrm{~cm})$, whereas the summer red cultivar showed shortest plant $(203.49 \mathrm{~cm})$. Tallest height was resulted might be due to suitable climatic conditions of the locality. [14] reported that transplantation time affected plant height of tomato up to the great extent and noted tall plants on early transplantation dates. [20] stated that maximum plant height was obtained in tomato plant when sowing was done earlier. In case of cultivars, the tallest height was obtained by the cultivar Anna which might be due to the suitability of cultivar with the environmental circumstances as well as genetic factor of the cultivar. According to [21] heightens, shortness and morphological traits are varietal differences, which are restricted and uttered by certain genes. The current outcomes are in conformity with the results reported by [22] they found Local Round cultivar of tomato had the highest plant height $(110.50 \mathrm{~cm})$.

\section{Stem diameter $(\mathrm{cm})$}

Recorded data for stem diameter $(\mathrm{cm})$ are presented in (Table 2). Analysis showed that stem diameter $(\mathrm{cm})$ was significantly influenced by transplantation dates and cultivars, while the interactive results were found non-significant. Data comparison for transplantation dates reflects that wider diameter of the stem $(2.12 \mathrm{~cm})$ was noted in the transplantation date $27^{\text {th }}$ of March, followed by $13^{\text {th }}$ March $(1.96 \mathrm{~cm})$, while the thin stem diameter $(1.77 \mathrm{~cm})$ was observed when the transplantation done on $03^{\text {rd }}$ April. Data regarding the cultivars displayed that widest diameter of the stem $(2.05 \mathrm{~cm})$ was noticed in cultivar Sahil, followed by cultivar Anna $(1.97 \mathrm{~cm})$, whereas the thin stem diameter was recorded in cultivar summer red $(1.84 \mathrm{~cm})$. Wider stem diameter was noted due to the optimal transplantation date. [23] declared that enlargement in tomato stem diameter was occurred with the early sowing dates as compared with the late sowing. In tomato the reduction in size of stem diameter was noted with delayed plantation dates due to poor vegetative growth of the plant [24]. Among the cultivars, widest stem diameter was noted in Sahil which might be due to the optimal growth conditions for the cultivar. Stem diameter also depends upon the genes and characteristics of the different cultivars. [25] recorded the minimum stem diameter $(9.11$ $\mathrm{mm}$ ) in tomato cultivar Nema-1200 while the maximum stem diameter $(14.95 \mathrm{~mm})$ in tomato cultivar Vegnesh during comparison.

\section{Days to flowering}

Data containing for days to flowering are existed in (Table 2). The flowering days were varied significantly among the transplantation dates, cultivars and their interaction. Data of transplanting dates showed that early flowering appearance (45.00 days) was noted when the 
transplantation done on $03^{\text {rd }}$ April, followed by (48.48 days) when transplantation was done on $27^{\text {th }}$ March, while the late flowering (56.50 days) was recorded when the transplantation done on $13^{\text {th }}$ March. Among the cultivars it is cleared from the mean table that the cultivar Sahil took least days to flowering (49.16 days), followed by cultivar Anna (50.88 days), while the cultivar summer red took maximum days to flowering (51.55 days) which was statistically similar with Anna cultivar. The early days to flowering were recorded might be due to increase in temperature as compared with the first transplantation date. [13] reported that tomato inflorescence was greatly affected by the early sowing dates and found that early sowing delayed the inflorescence in tomato. [26] also recorded the fluctuation in days to flowering of tomato genotypes and stated that this is in response of varied environmental conditions. The Sahil took least days to flowering might be due to hereditary trait of the cultivar. [25] reported that cultivar Nandi and Vegnesh took least days to flowering. According to [27] the tomato germplasm BINA Tomato-6 took maximum time to first flower appearance when compared with the other twenty one germplasm.

\section{Number of branches plant $\mathbf{t}^{-1}$}

Branches plant ${ }^{-1}$ data are presented in (Table 2). Data revealed that the number of branches plant ${ }^{-1}$ was influenced significantly by the transplantation dates and cultivars; however the interaction showed nonsignificant results. In transplantation dates more branches plant ${ }^{-1}$ (42.30) were noted when the transplantation done on $13^{\text {th }}$ March, followed by $20^{\text {th }}$ March (38.96), while the least branches plant ${ }^{-1}(30.68)$ were noticed when the transplantation done on $03^{\text {rd }}$ April. While in cultivars it is cleared from the mean table that the cultivar Anna records more branches plant ${ }^{-1}$ (41.73), followed by cultivar Sahil (37.63), while the cultivar summer red resulted in least branches plant ${ }^{-1}$ (31.50). According to the data the branches plant ${ }^{-1}$ were found decreased with the late transplantation, the reason might be due to increase in the local temperature. Branches plant ${ }^{-1}$ in tomato was considerably increased by the dissimilar sowing dates and found more branches on early sowing date [28]. The outcomes are strongly supported by [15] that with the late transplantation dates the number of branches plant $^{-1}$ was decreased. The cultivar Anna showed more branches plant ${ }^{-1}$ which might be due to the genetic factor of the cultivar. [29] found variation in number of branches plant $^{-1}$ in various cultivars of tomato in the experimental study. In different cultivars of tomato the number of branches varies from one another because of their hereditary characters [30]. In production of branches the differences among the cultivars might be due to their hereditary composition [31]. 
Table 2. Plant height (cm), Stem diameter (cm), Days to flowering and Number of branches plant $^{-1}$ as affected by tomato cultivars transplanted on various dates

\begin{tabular}{|c|c|c|c|c|}
\hline Transplanting Dates & $\begin{array}{c}\text { Plant Height } \\
(\mathbf{c m})\end{array}$ & $\begin{array}{c}\text { Stem Diameter } \\
(\mathbf{c m})\end{array}$ & $\begin{array}{c}\text { Days to } \\
\text { Flowering }\end{array}$ & $\begin{array}{c}\text { Number of } \\
\text { Branches Plant }^{-1}\end{array}$ \\
\hline $13^{\text {th }}$ March & $246.83 \mathrm{a}$ & $1.96 \mathrm{ab}$ & $56.50 \mathrm{a}$ & $42.30 \mathrm{a}$ \\
\hline $20^{\text {th }}$ March & $238.81 \mathrm{~b}$ & $2.12 \mathrm{a}$ & $52.15 \mathrm{~b}$ & $38.96 \mathrm{ab}$ \\
\hline $27^{\text {th }}$ March & $227.37 \mathrm{c}$ & $1.95 \mathrm{~b}$ & $48.48 \mathrm{c}$ & $35.87 \mathrm{~b}$ \\
\hline $03^{\text {rd }}$ April & $224.20 \mathrm{c}$ & $1.77 \mathrm{c}$ & $45.00 \mathrm{~d}$ & $30.68 \mathrm{c}$ \\
\hline LSD (0.05) & 5.90 & 0.16 & 2.35 & 3.61 \\
\hline Cultivars & & & & \\
\hline Anna & $258.37 \mathrm{a}$ & $1.97 \mathrm{ab}$ & $50.88 \mathrm{a}$ & $41.73 \mathrm{a}$ \\
\hline Sahil & $241.05 \mathrm{~b}$ & $2.05 \mathrm{a}$ & $49.16 \mathrm{~b}$ & $37.63 \mathrm{~b}$ \\
\hline Summer Red & $203.49 \mathrm{c}$ & $1.84 \mathrm{~b}$ & $51.55 \mathrm{a}$ & $31.50 \mathrm{c}$ \\
\hline LSD $(\mathbf{0 . 0 5})$ & 6.60 & 0.15 & 1.34 & 3.26 \\
\hline Interaction & & & & $\mathrm{NS}$ \\
\hline TD*Cv. & $\mathrm{NS}$ & $\mathrm{NS}$ & 2.69 & \\
\hline
\end{tabular}

Using LSD test values followed by dissimilar letters are significantly different at 0.05 level of probability.

\section{Days to harvesting}

Days to harvesting data are tabulated in (Table 3). Data showed that days to harvesting were significantly diverse between the transplantation dates and cultivars, while the interaction among the transplantation dates and cultivars was found non-significant. The values for transplantation dates indicate that early harvesting (73.53 days) were noted when the transplantation was practiced on $03^{\text {rd }}$ April, followed by transplantation date $27^{\text {th }}$ March (76.46 days), while the late harvesting (85.16 days) was noted in plants when the transplantation done on $13^{\text {th }}$ March. In case of cultivars the Sahil cultivar records least days to harvesting (75.56 days), followed by cultivar Anna (79.43 days), while the more days to harvesting (82.10 days) were noted by the cultivar summer red. The minimum days to harvesting were noted because with the late transplantation, fruits matured early due to increase in temperature. Variation in days to harvesting was also recorded by [32] during studying the transplantation date effects on tomato and noted earlier harvesting on late transplantation date. [33] explained that the range for days to harvesting of tomato cultivars varies from 70 to 120 days from the time of transplantation. Cultivar Sahil showed minimum days to harvesting as it took minimum days to flowering hence matures earlier and gave early harvest as compared with the other cultivars in the experiment. [22] concluded that tomato cultivar TT-0302 took least days (90.33) to harvesting during studying various tomato cultivars. The early or late harvesting is considered as genetic quality and to some extent influenced by the ecological factors of the particular growing region. [34] noted that the cultivar Naveen gave earliest fruit harvesting in direct sowing method, while the earliest fruit harvesting in transplanting method was given by the Vaishali cultivar. 


\section{Number of fruits plant ${ }^{-1}$}

Fruits number plant ${ }^{-1}$ data are shown in (Table 3). Data disclosed that fruits plant ${ }^{-1}$ was significantly influenced by transplantation dates and cultivars, the interactive results showed non-significant differences. The mean values exposed that more fruits plant ${ }^{-1}$ (81.50) were noted when the transplantation done on $13^{\text {th }}$ of March, followed by (76.67) transplanting date $27^{\text {th }}$ March, whereas the least fruits plant $^{-1}$ (68.47) was noted by the transplantation date $03^{\text {rd }}$ April. In case of cultivars, the cultivar Anna records more fruits plant $^{-1}$ (80.58), followed by Sahil cultivar (75.55 fruits), however the least fruits plant $^{-1}$ (67.37) among all the cultivars were given by the cultivar summer red. Tomato transplanted on $13^{\text {th }}$ March produced more fruits plant $^{-1}$ which might be due to the suitable environmental conditions of the locality. [35] examined the significant differences in fruits plant $^{-1}$ and stated that fruit numbers gradually decreased with the late transplantation in tomato. [36] observed more fruits cluster ${ }^{-1}$ by sowing tomatoes earlier of different cultivars in comparison with the late sowing date. [37] recorded more fruits in tomato plant from early transplantation instead of late transplantation. The cultivar Anna gave more fruits plant ${ }^{-1}$ as this cultivar produced maximum branches as well as records the tallest height; moreover the production life of Anna cultivar was long as compared to other cultivars so there was a high capacity for fruit production. [38] found significant difference for fruits plant ${ }^{-1}$ in various tomato cultivars during evaluation. Maximum fruits in one plant were also recorded by [39] from various varieties of tomato. Abinash variety of tomato showed more fruits plant $^{-1}$ in comparison to four tomato varieties [34].

\section{Fruit weight (g)}

Means regarding weight of the fruit $(\mathrm{g})$ are existed in (Table 3). Data showed that weight of the fruit was significantly varied among the transplantation dates and cultivars; however the interaction between the transplantation dates and cultivars showed non-significant differences. Data comparison for transplantation dates showed that heavy fruit weight (128.46 g) was recorded when the transplanting done on $13^{\text {th }}$ of March, which was statistically similar with $20^{\text {th }}$ March (126.03 g), whereas the least fruit weight $(120.19 \mathrm{~g})$ was recorded in plants when the transplantation done on $03^{\text {rd }}$ of April. Among the cultivars, mean table showed that Anna cultivar produced fruits with heaviest weight (133.43 g), which was statistically similar to Sahil cultivar (128.71 g), whereas minimum fruit weight was attained in summer red cultivar $(122.03 \mathrm{~g})$. With the late transplantation the reduction in fruit weight was noted, this might be due to rise in temperature because high temperature greatly affects tomatoes production. The outcomes are in line with the earlier study of [37] they concluded that transplantation dates significantly influenced the fruit weight of cultivar Gujrat tomato-2 and found decreased in fruit weight with delayed transplantation date. [40] reported that tomato fruit gained maximum weight with earlier sowing date while reduction in weight was noted when the sowing date was delayed. The outcomes are strongly supported with the statement of [12], they noticed that the reduction in weight of 
tomato fruit had occurred with the late transplantation date. The Anna cultivar attained maximum fruit weight among the tested tomato cultivars which might be due to the suitability of cultivar with the climate or due to its genetic makeup. Differences in weight of different tomato cultivars were

Table 3. Days to harvesting, Number of fruits plant ${ }^{-1}$, Fruit weight (g) and Fruit diameter (cm) as affected by tomato cultivars transplanted on various dates

\begin{tabular}{|c|c|c|c|c|}
\hline Transplanting Dates & $\begin{array}{c}\text { Days to } \\
\text { Harvesting }\end{array}$ & $\begin{array}{c}\text { Number of } \\
\text { Fruits Plant }^{-1} \\
\end{array}$ & $\begin{array}{c}\text { Fruit Weight } \\
(\mathrm{g})\end{array}$ & $\begin{array}{c}\text { Fruit Diameter } \\
(\mathrm{cm})\end{array}$ \\
\hline $13^{\text {th }}$ March & $85.16 \mathrm{a}$ & $81.50 \mathrm{a}$ & $128.46 \mathrm{a}$ & $4.98 \mathrm{a}$ \\
\hline $20^{\text {th }}$ March & $80.96 \mathrm{~b}$ & $76.67 \mathrm{~b}$ & $126.03 \mathrm{a}$ & $4.65 \mathrm{ab}$ \\
\hline $27^{\text {th }}$ March & $76.46 \mathrm{c}$ & $71.36 \mathrm{c}$ & $124.21 \mathrm{ab}$ & $4.47 \mathrm{~b}$ \\
\hline $03^{\text {rd }}$ April & $73.53 \mathrm{~d}$ & $68.47 \mathrm{c}$ & $120.19 \mathrm{~b}$ & $4.33 \mathrm{~b}$ \\
\hline LSD (0.05) & 1.19 & 4.05 & 4.86 & 0.44 \\
\hline \multicolumn{5}{|l|}{ Cultivars } \\
\hline Anna & $79.43 \mathrm{~b}$ & $80.58 \mathrm{a}$ & $133.43 \mathrm{a}$ & $5.00 \mathrm{a}$ \\
\hline Sahil & $75.56 \mathrm{c}$ & $75.55 \mathrm{~b}$ & $128.71 \mathrm{a}$ & $4.68 \mathrm{~b}$ \\
\hline Summer Red & $82.10 \mathrm{a}$ & $67.37 \mathrm{c}$ & $112.03 \mathrm{~b}$ & $4.15 \mathrm{c}$ \\
\hline LSD (0.05) & 1.85 & 3.05 & 5.96 & 0.28 \\
\hline \multicolumn{5}{|l|}{ Interaction } \\
\hline $\mathrm{TD}^{*} \mathrm{Cv}$ & NS & NS & NS & NS \\
\hline
\end{tabular}

Using LSD test values followed by dissimilar letters are significantly different at 0.05 level of probability

\section{Fruit diameter $(\mathbf{c m})$}

Diameter of fruit $(\mathrm{cm})$ data is tabulated in (Table 3). Results disclosed that diameter of the fruit was significantly influenced by transplantation dates and cultivars, whereas the interactive analysis showed nonsignificant results. Among the tested dates the greatest diameter of fruit $(4.98 \mathrm{~cm})$ was observed when the transplantation done on $13^{\text {th }}$ of March, followed by $20^{\text {th }}$ March $(4.65$ $\mathrm{cm})$. The smallest fruit diameter $(4.33 \mathrm{~cm})$ was obtained when the transplantation done on $03^{\text {rd }}$ April. In case of cultivars, (Table 3) showed that Anna cultivar resulted the fruits with maximum diameter $(5.00 \mathrm{~cm})$, followed by cultivar Sahil $(4.68 \mathrm{~cm})$, while the cultivar summer red produced fruits with also recorded by [27]. Average fruit weight of (361 g) was obtained by tomato cultivar Mountain Spring during the comparison of different tomato cultivars [41]. Similar results for fruit weight among different tomato cultivars were also found by [2]. 
cultivar were due to the reason that this cultivar also produced maximum fruit weight in comparison with the other cultivars as well as might be due to its genetic makeup because every cultivar has its own genetic makeup. [2] found maximum fruit diameter $(5.19 \mathrm{~cm})$ and minimum fruit diameter $(4.50 \mathrm{~cm})$ in tomato hybrids T-7010 and PTM-1603 respectively during studying the performance of various tomato hybrids.

\section{Fruit drop (\%age)}

The data related to fruit drop (\%age) are presented in (Table 4). Data demonstrate that fruit drop (\%age) was significantly varied by cultivars however the transplantation dates and interaction showed non-significant results. Among cultivars, the minimum drop of fruits were noted in cultivar Anna (4.87 \%), which was statistically similar with cultivar Sahil (6.46 $\%$ ), while the more number of fruit drop was noted in cultivar summer red $(10.15 \%)$. The maximum percentage of fruit drop was recorded in the summer red cultivar which might be due to its genetic nature as well as least adoptability to particular environmental conditions and its susceptibility to diseases. The separation or detachment of a fruit from the plant is considered as a fruit drop which is due to the biochemical and physiological changes. The fruit drop from the plant depends on cultivar or variety [43]. Selfincompatibility, water stress, insect, pest, disease infestations, hormonal imbalances, inadequate pollination and nutritional insufficiency are the chief causes for fruit drop in some cultivars of tomato [44]. Fruit drop was also recorded in some cultivars of walnut and pear by [45] during the comparison of different cultivars for the purpose of evaluation.

\section{Total soluble solids ( ${ }^{\circ}$ Brix)}

Total soluble solids ( ${ }^{\circ}$ Brix) data are shown in (Table 4). Analysis displayed that the total soluble solids $\left({ }^{\circ}\right.$ Brix) were significantly affected by cultivars, while the transplantation dates and interaction was noted non-significant. Data for cultivars revealed that maximum TSS contents was noted in cultivar Sahil (6.33 ${ }^{\circ}$ Brix $)$, followed by cultivar Anna (5.58 ${ }^{\circ}$ Brix), while the minimum total soluble solid contents (5.06 ${ }^{\circ}$ Brix) was recorded in summer red cultivar. The results showed that Sahil cultivar attained the highest content of total soluble solids, which might be due to its genetic factor. [12] observed variation in the amount of total soluble solids in various cultivars of tomato. [37] observed the fluctuations in total soluble solids of the Gujarat Tomato-2 variety in comparison of different varieties during the evaluation process. Significant results were noted for the total soluble solids in different genotypes of tomato by [39] showing maximum TSS (4.98\%) and minimum TSS (3.70\%) for tomato varieties Bambino and Money maker respectively. Variability in the degree of total soluble solids were also noticed by [46] during studying various tomato cultivars.

Yield (tons ha-1)

Yield (tons ha-1) data are given in (Table 4). Analysis disclosed that yield (tons ha ${ }^{-1}$ ) was significantly affected by transplantation dates, cultivars as well as by their interaction. According to (Table 4) the highest yield (92.72 tons ha-1) were obtained when the transplantation done on $13^{\text {th }}$ 
March, followed by $20^{\text {th }}$ March (90.58 tons $\mathrm{ha}^{-1}$ ), while the lowest yield (85.37 tons ha-1) were obtained when transplantation done on $03^{\text {rd }}$ April. In case of cultivars, it was noted that the cultivar Anna gave highest yield (95.16 tons $\mathrm{ha}^{-1}$ ), followed by cultivar Sahil (89.05 tons $\mathrm{ha}^{-1}$ ), while the minimum yield (83.30 tons $\mathrm{ha}^{-1}$ ) was obtained in cultivar summer red. Highest yield noted on $13^{\text {th }}$ March might be due to the optimum environmental conditions of the area. Tomato plants gave higher yield on early transplantation instead of late transplantation [37]. Maximum yield on early

Table 4. Fruit drop (\%age), Total soluble solids ( ${ }^{\circ}$ Brix), Yield (tons ha ${ }^{-1}$ ) and Disease incidence (\%age) as affected by tomato cultivars transplanted on various dates

\begin{tabular}{|c|c|c|c|c|}
\hline Transplanting Dates & $\begin{array}{c}\text { Fruit Drop } \\
(\boldsymbol{\%} \mathbf{a g e})\end{array}$ & $\begin{array}{c}\text { TSS } \\
\left({ }^{\circ} \mathbf{B r i x}\right)\end{array}$ & $\begin{array}{c}\text { Yield } \\
\left(\text { tons ha }^{-1}\right)\end{array}$ & $\begin{array}{c}\text { Disease Incidence } \\
(\% \mathbf{\% g e})\end{array}$ \\
\hline $13^{\text {th }}$ March & 5.86 & 5.70 & $92.72 \mathrm{a}$ & 2.60 \\
\hline $20^{\text {th }}$ March & 6.85 & 6.02 & $90.58 \mathrm{ab}$ & 3.06 \\
\hline $27^{\text {th }}$ March & 7.76 & 5.54 & $88.01 \mathrm{bc}$ & 3.33 \\
\hline $03^{\text {rd }}$ April & 8.17 & 5.37 & $85.37 \mathrm{c}$ & 3.87 \\
\hline LSD (0.05) & $\mathrm{NS}$ & $\mathrm{NS}$ & 3.14 & $\mathrm{NS}$ \\
\hline Cultivars & & & & $2.30 \mathrm{c}$ \\
\hline Anna & $4.87 \mathrm{~b}$ & $5.58 \mathrm{~b}$ & $95.16 \mathrm{a}$ & $3.20 \mathrm{~b}$ \\
\hline Sahil & $6.46 \mathrm{~b}$ & $6.33 \mathrm{~b}$ & $89.05 \mathrm{~b}$ & $4.12 \mathrm{a}$ \\
\hline Summer Red & $10.15 \mathrm{a}$ & $5.06 \mathrm{~b}$ & $83.30 \mathrm{c}$ & 0.76 \\
\hline LSD $(\mathbf{0 . 0 5})$ & 2.10 & 0.22 & 2.37 & \\
\hline Interaction & & & & $\mathrm{NS}$ \\
\hline TD*Cv. & $\mathrm{NS}$ & $\mathrm{NS}$ & 4.47 & \\
\hline
\end{tabular}

Using LSD test values followed by dissimilar letters are significantly different at 0.05 level of probability

\section{Disease incidence (\%age)}

The data for percent disease incidence (Early Blight and Late Blight) are tabulated in (Table 4). The results revealed that disease incidence (\%age) were significantly influenced by cultivars, while transplantation dates and interactive effect was found non-significant. Among the tested cultivars, (Table 4) showed that the least disease incidence was found in cultivar transplantation was also obtained by [12] in tomato crop. [40] revealed that tomato seeds when sown earlier gave higher yield instead of delayed sowing. The cultivar Anna produced highest yield because it formed maximum fruits as well as fruits with maximum weight and diameter. [25] found a significant difference in yield during the evaluation process of different tomato varieties. Variation in yield tons $\mathrm{ha}^{-1}$ was also noted by [2] during the comparison of various tomato genotypes at Peshawar climatic conditions. 
way to control tomato disease. [48] found that Zeal tomato genotype was resistant against different diseases during the evaluation of six tomato cultivars. The diseases in tomato plant could be control with the hereditary variation and resistance in cultivars [49]. Significant variation was also noted in term of disease incidence in different tomato cultivars by [50] during their experiment.

\section{Conclusions and Recommendations}

Analysis of the data displayed that transplanting dates and cultivars had significantly affected most of the studied parameters. In transplantation dates, the tallest plant, maximum number of branches plant $^{-1}$, fruits number plant ${ }^{-1}$, fruit weight, fruit diameter, yield, least fruit drop and disease incidence were noted in $13^{\text {th }}$ March tomato seedling transplantation. Thicker stem was noted in $20^{\text {th }}$ March. Early flowering and harvesting were recorded in $03^{\text {rd }}$ April. In case of cultivars, the tallest plant, more branches plant ${ }^{-1}$, number of fruits plant $^{-1}$, weight of fruit, diameter of fruit, yield, lowest fruit drop and disease incidence were recorded in Anna. Maximum stem diameter, total soluble solids, early flowering and harvesting were noted in Sahil cultivar. In the light of the outcomes and conclusions it may be recommended that; Anna cultivar and seedling transplantation date $13^{\text {th }}$ March may be recommended for better growth, higher yield and superior quality of tomato under the agro-climatic conditions of District Buner.

\section{Authors' contributions}

Conceived and designed the experiment: Shah FA \& Nabi G, Performed the experiment: Shah FA \& Shafiullah,
Analyzed the Data: Shah FA, Khan MN \& Rahman SU, Contributed reagents/ materials/ analysis tools: Rukh S \& Shah SMA, Wrote the paper: Shah FA.

\section{Acknowledgements}

The authors are thankful to Dr. Mohammad Sajjad (Director, ARS Buner), Mr. Muhammad Ilyas (PRO-Vegetable, ARI Mingora-Swat), Mr. Muhammad Ibrahim (Director, ARS Chitral), Dr. Abdul Bari (PRO-Oil Seed, ARI Tarnab-Peshawar), Mr. Abid Khan (SRO-Agronomy, ARS Buner), Mr. Saeed Ul Haq (AO-Horticulture, Agriculture Extension Department Buner) and Mr. Jawad Ali (Department of Agriculture, University of Swabi, AnbarPakistan) for their guidance and support.

\section{References}

1. Chohan TZ \& Ahmad S (2008). An assessment of tomato production practices in Danna Katchely, Azad Jammu Kashmir. Pak J of Life \& Soc Sci 6(2): 96-102.

2. Ali W, Jilani MS, Naeem N, Waseem K, Khan J, Ahmad MJ \& Ullah G (2012). Evaluation of different hybrid tomato under the climatic conditions of Peshawar. Sarhad J Agri 28(2): 207212.

3. FAO (2005). FAOSTAT, Available at http://faostat.fao.org, accessed on $20^{\text {th }}$ of May 2015.

4. Shahid R (1999). The effect of calcium prolonging the shelf life of tomato. M.Sc. thesis. Deptt. of Hort., Univ. Agri., Peshawar

5. Naika SJ, Van, Goffau M, Hilmi M \& Dam BV (2005). Cultivation of tomato, production, processing and marketing. Netherland. CTA. Series No. 17. 
6. Olaniyi JO, Akanbi WB, Adejumo TA \& Akande OG (2010). Growth, fruit yield and nutritional quality of tomato varieties. African J Food Sci 4(6): 398402.

7. Adenuga A, Lawal HAM \& Rotimi OA (2013). Economics and technical efficiency of dry season tomato production. Papers in Economics and Informatics in Selected Areas of Nigeria 5(1): 11-19.

8. Frusciante L, Carli P, Ercolano MRS, Pernice R, Matteo AD, Fogliano V \& Pellegrini N (2007). Antioxidant nutritional quality of tomato. Mol Nutr Food Res 51(5): 609-617.

9. Ejaz M, Rehman SU, Waqas R, Manan A, Imran M \& Bukhari MA (2011). Combined efficacy of macro-nutrients and micro-nutrients as a foliar application on growth and yield of tomato grown by vegetable forcing. Int J Agro Vet Med Sci 5(3): 327-335.

10. FAO. Food and Agriculture Organization (2017). www.fao.org/faostat/

11. Govt. of. Pakistan. MINFSR (2017-18). Fruits, vegetables and condiments statistics of Pakistan. Ministry of National food Security and Research Islamabad. pp. 17-18.

12. Madhumathi C \& Syed S (2013). Effect of different transplanting dates and varieties on fruit quality and seed yield of tomato (Lycopersicon esculentum L.) Asian J Hort 8(1): 8-11.

13. Peyvast GH (2001). Study of quality and quantity factors of tomato. $\mathrm{J} \mathrm{Veg}$ Crop Prod 10(1): 15-22.
14. Srivastava NK \& Srivastava AK (2007) Influence of gibberellic acid on ${ }^{14} \mathrm{CO}_{2}$ metabolism, growth, and production of alkaloids in Catharanthus roseus. Photosynthetic 45: 156-160.

15. Mira RD, Hossain T, Sultana MM, Sarwar G \& Rahman MS (2011). Variation in growth, yield and quality of tomato under different sowing time. Bangla Res Pub J 6(1): 72-76.

16. Wszelaki A \& Kleinhenz MD (2003). Yield and relationships among head traits in cabbage as influenced by planting date and cultivar-II processing. Hort Sci 38(7): 1355-1359.

17. Hamma IL, Ibrahim U \& Haruna M (2012). Effect of planting date and spacing on the growth and yield of sweet pepper (Capsicum annuиm L.) in samara area of Zaria in Nigeria. Nigerian J Agri Food \& Env 8(1): 6366.

18. Ahammad KU, Siddiky MA, Ali Z \& Ahmed R (2009). Effects of planting time on the growth and yield of tomato varieties in late season. Progressive Agric 20(2): 73-78.

19. Steels RGD, Torrie JH \& Dickie DA (1997). Principles and procedures of statistics. A biometric approach, $3^{\text {rd }}$ edit. USA. McGraw-Hill publishing company, Toronto. ISBN 10: 0070610282.

20. Sharma SK (1995). Response of boron and calcium nutrition on plant growth, fruit and seed yield of tomato. Veg Sci 22(1): 27-29.

21. Ahmad FO, Khan S, Sarwar A, Hussain \& Ahmad S (2007). Performance 
evaluation of tomato cultivars at high altitude. Sarhad J Agri 23(3): 581-585.

22. Zahoor A, Sajid M, Haq S, Ahmed S \& Ali F (2006). Performance of tomato lines under the climatic conditions of Mingora-Swat. Sarhad J Agri 22(2): 221-224.

23. Szckely G, Bernathe J \& Nemeth E (2002). Floral biological characteristics and fruit development of fennel. Acta Hort 5(9): 159-162.

24. Ishida K (1991). Ujinira, Hiramantsy, Field. Crop. Abstr: 2530.

25. Jilani MS, Waseem K, Ameer K, Jilani TA, Kiran M, Alizia AA \& Parveen A (2013). Evaluation of elite tomato cultivars under the agro-climatic conditions of Dera Ismail Khan. Pak J Agri Sci 50(1): 17-21.

26. Mehmood N, Ayub G, Ullah I, Ahmad N, Noor M, Khan AM, Ahmad S, Saeed A \& Farzana (2012). Response of tomato (Lycopersicon esculentum Mill.) cultivars to nitrogen levels. Pure Appl Biol 1(3): 63-67.

27. Islam (2004). Performance of four tomato varieties under different levels of salinity. M.Sc. thesis. Deptt. of Hort., Univ. Mymensingh., Bangladesh

28. Bisaria AK \& Sham SA (1979). Effect of different seasons on growth and yield attributes of okra (Abelmoschus esculentus L.) Haryana. J Hort Sci 2(3): 156-157.

29. Sharma SK \& Rastogi KB (1993). Evaluation of some tomato cultivars for seed production under mid hill conditions of Himachal Pardesh. Annals of Agric Res India 14(4): 494-496.
30. Davis JM, Sanders DC, Nelson PV, Lengnick L \& Sperry WJ (2003). Boron improves growth, yield, quality and nutrients contents of tomato. J Ami Soc Hort Sci 128(3): 441-446.

31. Khan MN, Ayub G, Ilyas M, Khan M, Haq FU, Ali J \& Alam A (2016). Effect of different mulching materials on weeds and yield of Chili cultivars. Pure Appl Biol 5(4): 1160-1170.

32. Moraru C, Logender L, Lee TC \& Janes $H$ (2004). Characterization of 10 processing tomato cultivars grown hydroponically for the NASA advanced life support program, USA. J Food Composition and Analysis 7: 141-154.

33. Shah AH, Munir SU, Amin NU \& Shah SH (2011). Evaluation of two nutrient solutions for growing tomatoes in a non-circulating hydroponics system. Sarhad J Agric 27(4): 557-567.

34. Jaha JC \& Krishi B (2001). Studies on performance of different tomato hybrids in off-season under different planting methods in Terai agro-climatic zones of West Bengal, India. J Inter Academicia 5(2): 186-189.

35. Islam S, Islam MM, Siddik MdA, Afsana N, Rabin MH, Hossain MdD \& Parvin S (2017). Variation in growth and yield of tomato at different transplanting date. Int J Sci \& Res Pub 7(2): 143-145.

36. Dey SC (2000). Tomato crop in vegetable growing. Agrobiose, New Dehli, India. pp. 59-61.

37. More SJ, Bhanderi DR, Patil SJ, Kadam YR \& Patel JC (2013). Effect of transplanting dates and mulching on fruit characters, yield and quality of 
tomato (Lycopersicon esculentum L.) cv. Gujrat Tomato-2 Crop. Res Int J 46(3): 185-187.

38. Solis A, Martinez R, Moya C, Domini ME, Lopez V, Milan E \& Amat I (2006). Behavior of tomato (Lycopersicon esculentum Mill.) varieties within two seeding periods in Velasco, Holguin. Cultivos Tropicales 27: 51-52.

39. Ali A, Hussain I, Khan A, Khan J, Rahman MU \& Riaz A (2016). Evaluation of various tomato (Lycopersicon esculentum Mill.) cultivars for quality, yield and yield component under agro-climatic condition of Peshawar. ARPN J Agri Biol Sci 11(2): 59-62.

40. Hossain MF, Ara N, Islam MR, Hossain J \& Akhter B (2013). Effect of different sowing dates on yield of tomato genotypes. Int J Agril Res Innov \& Tech 4(1): 40-43.

41. Gardner RG (2006). "Mountain Crest" Hybrid tomato and its parents, NC 1 rinEC. Hort. Sci. A publication of the Amer society for Hort science 41(1): 261-262.

42. Kamali S, Moaveni P, Valadabadi SA \& Mehraban A (2016). Effect of sowing dates on the morphological traits and fruit yield of bitter gourd. J Agric Biol Sci 11(12): 458-462.

43. Moneruzzaman KM, Jahan SM, Nashriyah M \& Nasrulhaq BA (2015). Bioactive constituents, antioxidant and antimicrobial activities of three cultivars of wax apple (Syzygium samarangense L.) fruits. Res J Biotech 10(1): 7-16.
44. Singh JK, Prasad J, Singh HK \& Singh A (2008). Effect of micro-nutrients and plant growth regulators on plant growth and fruit drop in Aonla (Emblica officinalis Gaertn.) fruits cv. 'Narendra Aonla-10'. Plant Archives 8(2): 911913.

45. Garai M \& Pompoli F (2005). A simple empirical model of polyester fiber materials for acoustical applications. Appl Acoustics 66: 1383-1398.

46. Yagmur B, Okur B \& Ongun AR (2004). Effects on enhanced potassium doses on yield, quality and nutrient uptake of tomato. IPI regional workshop on potassium and fertigation development in West Asia and North Africa; Rabat, Morocco. pp. 24-28.

47. Zeshan MA, Khan MA, Ali S \& Arshad M (2016). Phenotypic evaluations of tomato germplasm for the source of resistance against tomato leaf curl virus disease. J Anim Plant Sci 26(1): 194200.

48. Baliyan SP \& Rao MS (2013). Evaluation of tomato varieties for pest and disease adaptation and productivity in Botswana. Inter J Agri \& food Res 2(3): 20-29.

49. Hulbert SH, Webb CA, Smith SM \& Sun Q (2001). Resistance gene complexes: evolution and utilization. Ann Rev Phytopathol 39: 285-312.

50. Meya AI, Mamiro DP \& Kusolwa P (2015). Response of late blight disease resistant variety to common occurring tomato diseases in the field. Asian $J$ of Plant Sci \& Res 5(6): 8-15. 